\title{
Border Control Technologies of Western Nations: Legal, Ethical and Financial Issues
}

\author{
Mohammad Mushfequr Rahman \\ Department of Computer Science, University of Bath, Somerset, United Kingdom \\ Email address: \\ Mr2002@bath.ac.uk \\ To cite this article: \\ Mohammad Mushfequr Rahman. Border Control Technologies of Western Nations: Legal, Ethical and Financial Issues. International \\ Journal of Science, Technology and Society. Vol. 9, No. 6, 2021, pp. 256-262. doi: 10.11648/j.ijsts.20210906.11
}

Received: September 7, 2021; Accepted: October 11, 2021; Published: November 5, 2021

\begin{abstract}
While in the past border control was mostly about military and political supremacy today it is being enhanced often to protect the public resources, culture, population and to maintain social security. A brief history of border control technologies has been discussed and then how it evolved from simple border protection to complex ethnic, national and cultural protection. Border control techniques utilize air, land, naval and biometric technologies to preserve the border and ethnic and socio-cultural integrity of western countries. The objective of this study was to understand cost of such technologies, its effects on human rights and existing laws to address such violations of human rights. The analysis has been a systematic review of existing and evolving technologies. Various journals and papers, public and private research organizations have been examined in this regard. The paper finds that such technologies cost high, have harmed human rights and at the same time necessary laws have not been developed to tackle these violations. The paper proposes that to establish equitable and proportionate use of such technologies an international mechanism must be developed through the UN which must ensure proper legal and ethical framework is set up to maintain and function these advanced technologies while optimizing costs and environmental impact.
\end{abstract}

Keywords: Border Control, Refugees, Immigrants, Migration

\section{Introduction}

Today we have various technologies and mechanisms to deal with our borders. Almost every country has border control mechanism. Border control has become synonymous to social stability and national security. That is clear if anyone sees the political and legal activities of world nations. However, border control was not so strict in history of the world. In fact borders were open by today's standards. It rose out of treaties mainly. We see this in Peace of Callias treaty where Persians and Greeks agreed for a truce and agree between themselves a marked territory [1]. In Roman Empire we see a "network of walls, rivers, desert forts, and mountain watchtowers" as it's border control protocol [2]. Apart from these man-made systems, mountains, dense forests and hostile landscapes were also part of the border control mechanism of the ancient world as it is today as we see in case of Iran and Afghanistan. In ancient Britain Hadrian's wall was a clear example of a border control mechanism of Roman empire [3]. It is clear then that in ancient world such steps were taken to ensure political and military ownership of a land. Unlike in modern times border control mechanism exists and is being enhanced often to protect the public resources, culture, population and to maintain social security. It is not to protect political or military ownership of a land. This is the sense in peace time. It is because since the enactment of UN Charter 1945 borders are no longer seen being threatened by foreign armies, even though there have been invasions, but this is not the de jure standard like the ancient world.

Modern developed nations are careful about over immigration because they feel it threatens the local job market, threatens the allocation of public resources and threatens the social security and the culture of the people, yet many feels that more immigration can bring in skills and minds to benefit the economy, as well as feel ethically obliged to assist their former colonies, including the belief of a shared human heritage of diversity. This is mainly true when immigrants are coming from war zones. Towards these ends borders had to be enhanced and protected through sophisticated technologies as purely manpower enabled 
protection was no more feasible. Such technologies have created issues relating to national budget, migration, human welfare and accountability.

Some questions that arise from the emergence of such technological sophistication are how much do these technologies cost? What is the human impact of these technologies? How are these monitored and what laws have been designed to achieve these?

\section{Method}

The analysis has been a systematic review of existing and evolving technologies. Various journals and papers, public and private research organizations have been examined in this regard.

\section{Results}

Technologies for securing borders are being developed without consideration of national welfare and thought of refugee. Cultural, political and social considerations of nation states have overwhelmed the human factor. These technologies are not monitored internationally as to their nature of use and protocols. I have given an example of externalization as an issue of human rights.

US, UK and EU have advanced border control technologies. Multiple agencies of governments are working together to secure the borders. These technologies have an impact on national budget, sometimes huge and on the environment. Even though world has become extremely globalized our borders have not.

\section{Discussion}

\subsection{History of Border Control: USA}

In order to protect the national resources and social security of USA, it has been taking steps since as early as 1904. It initially consisted of mounted patrols whenever resources allowed such [4]. However a real border patrol system was created in 1924 within the department of Commerce and Labor. It was a time when alcohol was prohibited. The initial task of this newly created system was to prevent Chinese migrants, combating alcohol and firearms trafficking [4]. Finally USBP was incorporated in to department of Justice in 1940 [5]. The USBP focused on particular areas of the United States and gradually included more and more of the US borders [5]. Congress emphasized the border enforcement in Immigration Reform and Control Act 1986, increasing the budget for border control by $50 \%$ [5]. Border patrol had become border enforcement.

First border strategy was developed in 1994 with updates in 2004 and 2012. The strategy had several operations each adding new staff, technologies and infrastructure [5]. Other major border control mechanism were the DHS Secure Border Initiative of 2005 and CBP [5]. These added new staffs, technologies, infrastructures and protocols as well.

We see that US border control system developed gradually and at times hastened by needs and emergencies as it unfolded and as new technologies emerged and developed.

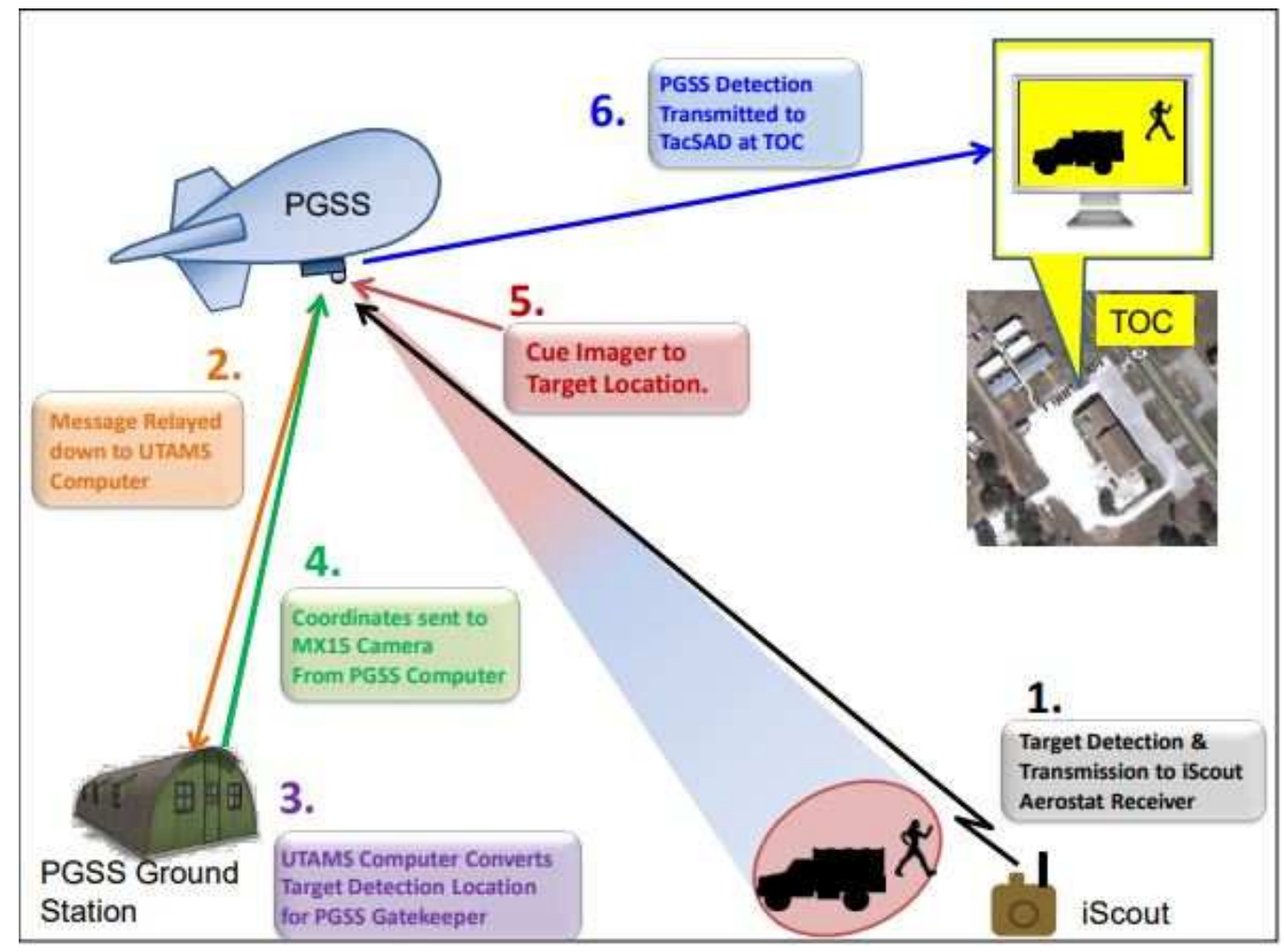

(Dtic.mil, 2011)

Figure 1. PGSS Operational Activity. 


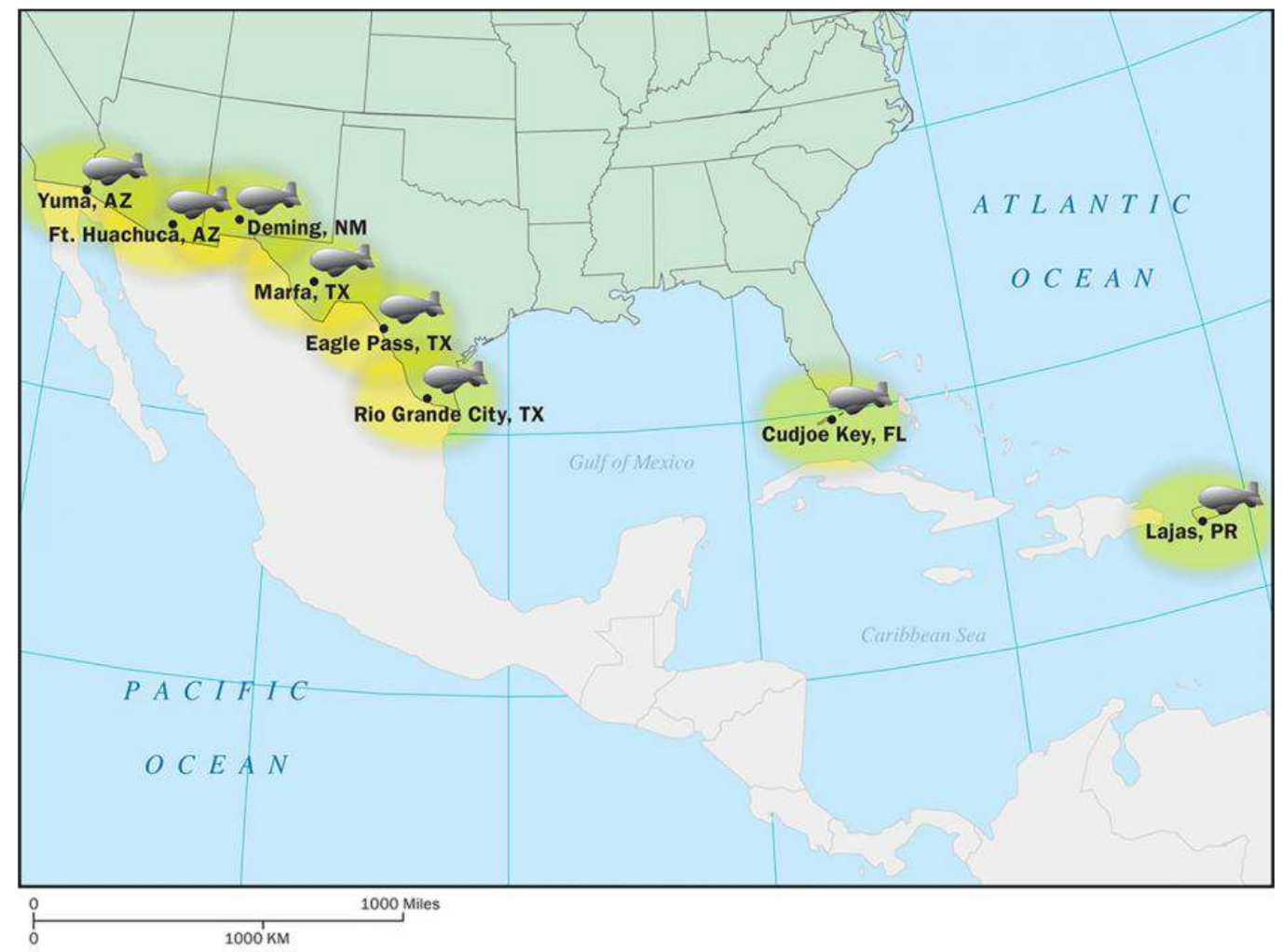

(Cbp.gov, 2018)

Figure 2. CBP located TARS on the Southwest border to overlap coverage and detect flights from Mexico, Central and South America.

\subsection{Border Control Technologies of US, UK and European Union}

\subsubsection{Land Technology of USA}

Probably the first technology US border patrol used was ISIS. ISIS was deployed around 1998 [5]. It consisted of sensors, cameras (Remote Video Surveillance), ICAD and databases. RVS uses RFID technology to monitor selected portion of the border [5]. Sensors of thermal, seismic and magnetic nature are buried in ground which once detects any activity send a signal through RFID technology to communications center and registered in ICAD notifying the law enforcement officers [5]. Of about 255 numbers of RVS components use cameras, poles and radio equipment to send microwave signals to communication center [6]. Sensor sensitivity level can be adjusted and this technology is easy to use and install [7]. This system however is prone to environmental damage such as heat and moisture among other things [7] as well as damaging the environment such as trees and cultivated lands [5]. ISIS components are not fully automated as cameras and sensor synchronization must be made manually [7]. In 2005 ISIS was incorporated into ASI [5].

\subsubsection{Aerial and Maritime Surveillance Technology of USA}

Air and Maritime Operations use UAS as well as manned flights for places considered to be too dangerous. As of Oct 201519 types of aircrafts and 3 types of marine vessels have been used [5]. US Department of Defense is also supportive in the border monitor system as it provides advanced systems such as unmanned aerostat systems, PGSS and RAID [5]. The aerostat system is affected by various environmental factor such as cold and heat and has very specific and detailed requirements [6]. Two important requirements for unmanned aerostat operation are PGSS and RAID.

PGSS is the "eye in the sky" according to CBP. It can fly $10,000 \mathrm{ft}$ high with an observational radius of 200 miles. It has a radar at the bottom which can sweep anything that goes within 200 miles. This data is sent to AMOC which can integrate to more than 700 sensor feeds such as iScout to monitor over 50000 aircrafts in flight over USA [9].

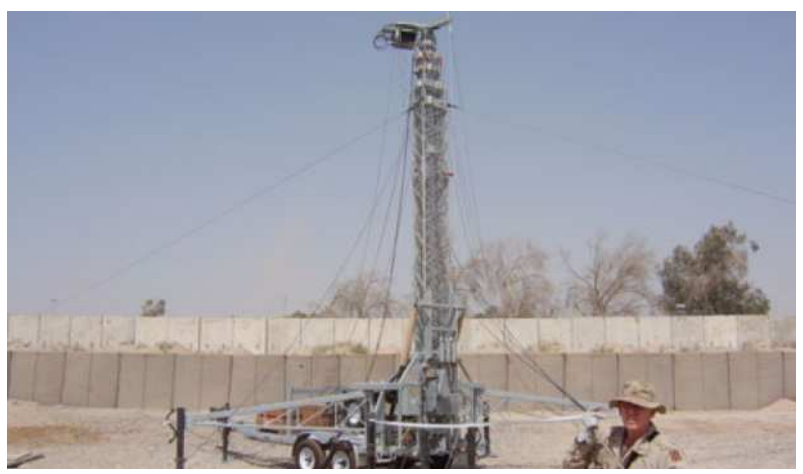

(Galvanizeit.org, 2005)

Figure 3. RAID System.

RAID system consists of sensors which can detect movements at great distance. 


\subsection{Airport Security}

In 2001 CAPPS was developed in response to the $9 / 11$ terrorist attacks. In 2004 it was cancelled due to human rights issued as criticized by various human rights activists. CAPPS had a predictive modelling based on passenger buying patterns. It flagged passenger actions has suspicious based on these patterns, as well as it matched passengers against a watchlist [10]. The new system Secure Flight Passenger Screening program however kept the later feature [11].

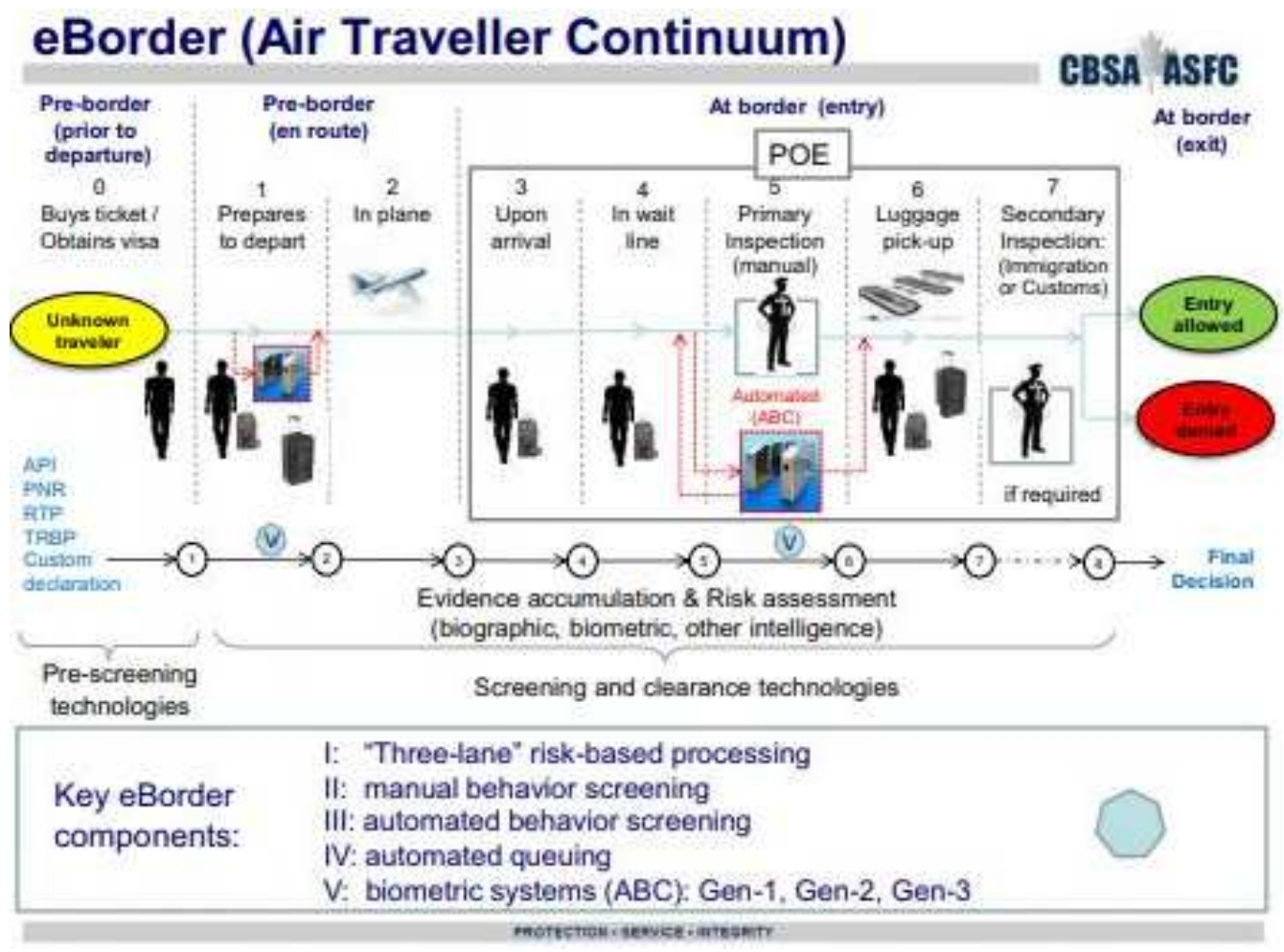

Figure 4. (Defence Research and Development Canada, 2015).

\subsection{United Kingdom E-Border}

E-Border is automated border control and management specifically for air mode transportation. $\mathrm{ABC}$ machine is the main component in this E-Border task [11]. Current generation $\mathrm{ABC}$ machine is an automated system which identifies the e-MRTD which establishes whether the identification belongs to the said individual according to certain pre-established rules [11].

\subsection{European Union Frontex}

EU's FRONTEX which is the border control agency has four border control projects in place:

1) Operation Hera II (2006).

2) Operation Indalo and Minerva (2007).

3) EUROSUR (2013).

Among these EUROSUR has been technologically advanced, consisting of drones, radars, sensors and satellite tracking systems. EUROSUR shares it's data with SIS, VIS and EURODAC [12]. These mechanisms obtain fingerprints and facial images of incoming people. Intensive biometric technologies are used:

1) Retina printers.

2) Iris prints.

3) Finger prints.
4) Gait prints.

5) Facial thermograms.

6) Voice prints.

7) Bone scans.

8) DNA Processors [3].

\subsection{Consequences of Border Technology}

US border technologies have had successes in protecting its borders. If we consider PGSS technology we can see the successes it had in preventing illegal border infiltration and apprehension of illegals. Some examples are noteworthy:

1) In 2013 detected about 586 unknow flights.

2) In 2014 an unknown aircraft without a transponder was detected which led to the capture of $2000 \mathrm{~kg}$ of Marijuana. [13]

Even though such advancements have been made in border control technologies these are not without defects. For example the aerostat system must be replaced every five to six years due to tear caused by sunlight and wind [13]. Also not all areas of US border are covered which lets many illegals pass through. The system cannot detect camouflage used by the illegals using terrain features [13]. The system is also costly requiring fuel change every four days [12].

In Europe drones are used to save lives at sea. Refugees and migrants from Africa often die in the Mediterranean. Drones 
are used to locate and rescue many of these people. However it is noteworthy that these technologies are primarily used to secure Europe's border but not to save lives [12].

As to UK IRIS project, some of it's technologies sometimes can cause delays in passenger checking and wrong rejection of a passenger [14].

\subsection{Human Rights Issues and Border Control Technologies}

Externalization is the transfer of border management to third parties, in this case foreign nations [15]. Externalization is really a shrewd political move. European leaders very well know they cannot intentionally and openly violate human rights by taking strict measures against refugees and immigrants. They know some Eastern European, Turkish, Arab and African leaders have a record of violating human rights of people, of their subjects and of foreigners. It is no secret and well documented [17, 18]. Hence European leadership made the move to externalization so that these human right violators could harshly take care of the incoming refugees and immigrants fleeing war and persecution. Let us take the case of Sudan. Sudan's Eritrean hunt is notable. Sudan is capturing and deporting Eritreans back to Eretria which is a ferocious dictatorship [15]. The externalization agreements are not transparent and undemocratic [15]. International law protects these refugees who are fleeing war and persecution [18] and according to Universal Declaration of Human Rights everyone has the right to seek and enjoy asylum in other countries from persecution [19].

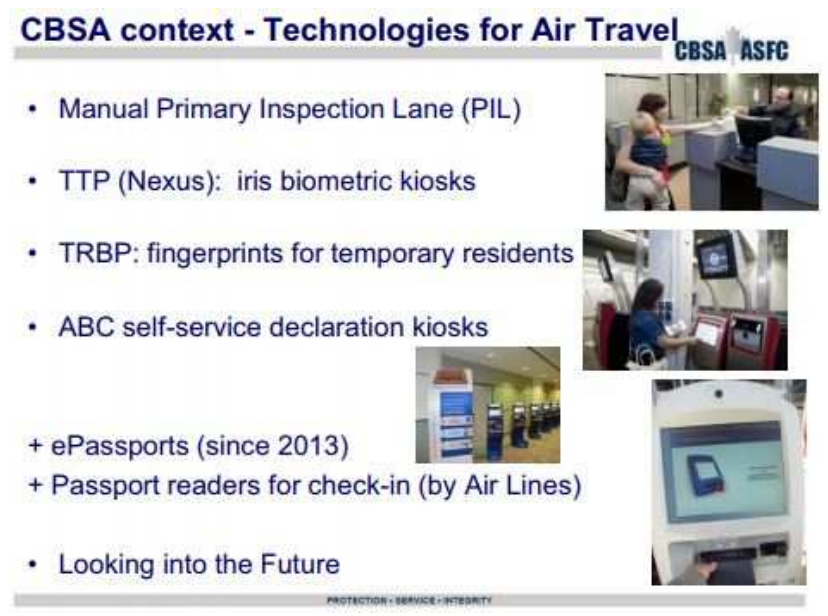

(ibid)

Figure 5. Airport Screening Technologies.

Externalization is an infringement of International law and a impediment against the concept of global harmony in a global society. If we want to deal with the Refugee crisis we need to deal with it's root problems. The main problem of nations is non-adherence to international law. UN Charter was envisioned to promote international peace (UN charter, Article 1-2). However countries waging wars of aggression and backing and supporting dictatorships have caused a massive refugee crisis. This is evident from wars against Iraq, Afghanistan, Libya and Syria. It is a common sense that when there is war people will flee. When there is persecution people will flee. However we must ensure that border technologies must be used to help and protect these fleeing people, but not to turn them over to tyrants and dictators.

Biometric data collection is another major concern. This data can be used for social sorting and hence restricting mobility of certain groups of people [12]. Biometric data collection is also violation of privacy as it is related to the person's internal self in contrast to external identity such as passport or driving license which can be changed. Hence collecting biometric data of an individual marks him permanently. These biometric data are stored in sophisticated databases such as EURODAC and VIS. The danger of collection and storing lies actually in it's sharing with third parties who have been known to be harmful and aggressive. Western intelligence share data among themselves. Here for example Five Eyes is a collation of five countries' spy networks: US, UK, Canada, New Zealand and Australia. Data sharing agreement was reached through UKUSA agreements [20]. We do not know what they do with this data. We do know however that these spy agencies monitor people and collect their information [21]. Wikileaks and Snowden are common knowledge of every people today. Spy agencies may use collected biometric data for various proposes all to ensure one purpose: National security. This is a vague word and it can be used to do any thing from assassination to democratically elected government overthrow. There must be an international mechanism to regulate collection of private data. International law should guide the collection and use of such data so that it is not used to do harm to any people or country.

This is only the first world countries who are abusing these technologies. Imagine what would happen if some of these technologies fall in the hands of third world dictators. Giving an example of Malaysia will suffice. Malaysia is not a party to 1951 Refugee Convention. Malaysia is not willing to consider refugees or even treat them humanely. Vast number of refugees fleeing real persecution end up in Malaysia with no right to work, study or travel. Many of them are treated as illegal immigrants and packed up like sardines in overcrowded, unsanitary immigration centers [17]. These are some of the many abuses that refugees face once they cross Malaysian borders. Some of the digital technologies that Malaysia use are drones, satellite systems and HD CCTV [22].

Moving to non-state actors if these technologies ended up in the hands of terrorists it would be a disaster. The truth is this disaster has happened. Recently Russia has repelled thirteen drone attacks by the so called ISIS, also known as Daesh [23]. This kind of sophisticated technology ending up at terrorist hands is really something that needs consideration and questioning as to it's source. The important thing here is civilians are not Russian military. They won't be able to defend against one drone attack let alone thirteen drones.

\subsection{Emerging Technologies}

Artificial Intelligence is the future of border control. US has invested in this project which will run through 2020. 
Here for example "University of Arizona researchers have been working on is an autonomous artificial intelligence framework that uses real-time data to work out how best to deploy various high-tech resource - ranging from ground vehicles and drones to smart sensors, and other technologies — to surveil the 1,900-mile-long border with Mexico" [24].

\section{Conclusion}

Border control started as a political and military protectorate and issue, gradually becoming a more social, cultural and economic concerns. Today no longer the military protects borders but specialized border security forces. From watch tower, walls and scouts to advanced digital technologies have evolved the history of border protection and technologies. Various advanced systems are used by developed countries which have many benefits with high costs as well as have given rise to human rights issues. These technologies apart from benefitting the country and protecting it's borders also are being used to violate our privacies and human rights not just by the governments who we are supposed to trust but by terrorists also whom we must be protected against. Border technologies are evolving gradually side by side with digital technologies. One empowers the other. We must, at the same pace evolve our mechanism, laws and regulations so that these technologies do not harm us more than they benefit us.

\section{Recommendation}

New technologies must pass the human and environmental welfare test: they should not be lethal; they should not be damaging to the environment, and they should not cost high unnecessarily and above all they should protect the border including the incoming migrants and refugees rather than being executioners of them. Towards this end such technologies might be designed to record the identities of all incoming refugees and migrants. These technologies must be monitored how they are used, and so proper international legal mechanisms established so that they are not abused or exploited by powerful or interested parties. These technologies must be utilized best to help the unfortunate ones fleeing war, fight organized crimes and understand global migration patterns to lessen human suffering.

\section{List of Abbreviation}

$\begin{array}{ll}\text { ABC } & \text { Atanasoff Berry Computer } \\ \text { AMOC } & \text { Air and Marine Operations Center } \\ \text { ASI } & \text { America's Shield Initiative } \\ \text { CAPPS } & \text { Computer-Assisted Passenger Prescreening } \\ \text { CBP } & \text { System } \\ \text { DHS } & \text { U.S. Customs and Borders Protection } \\ \text { E-BORDER } & \text { Department of Homeland Security } \\ & \text { Electronic Border }\end{array}$

\begin{tabular}{|c|c|}
\hline E-MRTD & $\begin{array}{l}\text { Electronic Machine Readable Travel } \\
\text { Documents }\end{array}$ \\
\hline EURODAC & European Dactyloscopy \\
\hline EUROSAR & $\begin{array}{l}\text { European External Border Surveillance } \\
\text { System }\end{array}$ \\
\hline HD CCTV & High Definition Closed Circuit Television \\
\hline ICAD & Intelligent Computer Aided Detection \\
\hline IRIS & Iris Recognition Immigration System \\
\hline ISIS & Integrated Surveillance Information System \\
\hline PGSS & Persistent Ground Surveillance System \\
\hline RAID & Rapid Aerostats Initial Deployment \\
\hline RFID & Radio Frequency Identification \\
\hline RVS & Remote Video Surveillance \\
\hline SIS & Schengen Information System \\
\hline TARS & Tethered Aerostat Radar System \\
\hline UAS & Unmanned Aircraft Systems \\
\hline UN & United Nations \\
\hline USBP & United States Border Patrol \\
\hline VIS & Visa Information System \\
\hline
\end{tabular}

\section{References}

[1] Encyclopedia Britannica. (2018). Ancient Iran. [online] Available at: https://www.britannica.com/place/ancient-Iran [Accessed 8 Mar. 2018].

[2] Ngm.nationalgeographic.com. (2012). Roman Frontiers Pictures, More From National Geographic Magazine. [online] Available at: http://ngm.nationalgeographic.com/2012/09/romanwalls/curry-text [Accessed 8 Mar. 2018].

[3] Wall?, W. (2016). What is Hadrian's Wall?. [online] HISTORY.com. Available at: https://www.history.com/news/ask-history/what-is-hadrianswall [Accessed 8 Mar. 2018].

[4] Cbp.gov. (2017). Border Patrol History | U.S. Customs and Border Protection. [online] Available at: https://www.cbp.gov/border-security/along-us-borders/history [Accessed 8 Mar. 2018].

[5] Fas.org. (2016). Border Security: Immigration Enforcement Between Ports of Entry. [online] Available at: https://fas.org/sgp/crs/homesec/R42138.pdf [Accessed 8 Mar. 2018].

[6] Gao.gov. (2018). Cite a Website - Cite This For Me. [online] Available at: https://www.gao.gov/assets/250/249053.pdf [Accessed 8 Mar. 2018].

[7] Pike, J. (2018). ISIS. [online] Globalsecurity.org. Available at: https://www.globalsecurity.org/security/systems/isis.htm [Accessed 8 Mar. 2018].

[8] Army Research Laboratory (2007). Weather Impacts on the Aerostar Unmanned Aircraft System Based on Climatology over the U.S./Mexico Border. ARL-TR-4055. [online] Army Research Laboratory. Available at: http://www.dtic.mil/get-trdoc/pdf?AD=ADA464136 [Accessed 8 Mar. 2018].

[9] Dtic.mil. (2011). (PGSS) Cueing Demonstration. [online] Available at: http://www.dtic.mil/dtic/tr/fulltext/u2/a545592.pdf [Accessed 8 Mar. 2018]. 
[10] Rand.org. (2006). [online] Available at: https://www.rand.org/content/dam/rand/pubs/reprints/2006/R AND_RP1216.pdf [Accessed 11 Mar. 2018].

[11] Pike, J. (2011). CAPPSII. [online] Globalsecurity.org. Available at: https://www.globalsecurity.org/security/systems/cappsii.htm [Accessed 11 Mar. 2018].

[12] Pater, M. (2014). A never-ending journey at the external borders of the European Union. Masters. Utrecht University.

[13] Cbp.gov. (2018). Frontline November Aerostats | U.S. Customs and Border Protection. [online] Available at: https://www.cbp.gov/frontline/frontline-november-aerostats [Accessed 8 Mar. 2018].

[14] Defence Research and Development Canada (2015). Automated Border Control systems as part of e-border crossing process.

[15] CURZI, C. (2016). The externalisation of European borders $/$ Open Migration. [online] Open Migration. Available at: https:/openmigration.org/en/analyses/the-externalisation-ofeuropean-borders-steps-and-consequences-of-a-dangerousprocess/ [Accessed 11 Mar. 2018].

[16] Ohchr.org. (2018). OHCHR | OHCHR Human Rights Programme for the Middle East and Northern Africa Region. [online] Available at: http://www.ohchr.org/EN/Countries/MENARegion/Pages/ME NAProgramme.aspx [Accessed 11 Mar. 2018].

[17] Human Rights Watch. (2018). World Report 2017: Rights Trends in European Union. [online] Available at: https://www.hrw.org/world-report/2017/countrychapters/european-union [Accessed 11 Mar. 2018].

[18] Refugees, U. (2001). Refugee Protection: A Guide to
International Refugee Law (Handbook for Parliamentarians). [online] UNHCR. Available at: http://www.unhcr.org/enmy/publications/legal/3d4aba564/refugee-protection-guideinternational-refugee-law-handbook-parliamentarians.html [Accessed 11 Mar. 2018].

[19] Un.org. (1948). Universal Declaration of Human Rights. [online] Available at: http://www.un.org/en/universaldeclaration-human-rights/ [Accessed 11 Mar. 2018].

[20] Calhoun.nps.edu. (2017). Cite a Website - Cite This For Me. [online] Available at: https://calhoun.nps.edu/bitstream/handle/10945/56946/FiveEy es_CIOs_Hold_Annual_Defense_Forum_at_NPS.pdf?sequenc

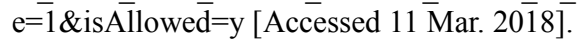

[21] MacAskill, E., Borger, J., Hopkins, N., Davies, N. and Ball, J. (2013). GCHQ taps fibre-optic cables for secret access to world's communications. [online] the Guardian. Available at: https://www.theguardian.com/uk/2013/jun/21/gchq-cablessecret-world-communications-nsa [Accessed 11 Mar. 2018].

[22] Malaysian Digest. (2017). Strengthening Border Control: China Agrees To Transfer Technology, Shares Yunnan's Experiences, Says Zahid. [online] Available at: $\mathrm{http} / /$ malaysiandigest.com/frontpage/282-main-tile/653048strengthening-border-control-china-agrees-to-transfertechnology-shares-yunnan-s-experiences-says-zahid.html [Accessed 11 Mar. 2018].

[23] RT International. (2018). US 'concerned' that drones used in attacks on Russian bases in Syria available in 'open market'. [online] Available at: https://www.rt.com/usa/415314-pentagonsyria-isis-drones-concerns/ [Accessed 11 Mar. 2018].

[24] Digital Trends. (2018). Drones, smart sensors, and AI may soon guard the U.S. border. [online] Available at: https://www.digitaltrends.com/cool-tech/smart-border-controlproject/ [Accessed 25 Mar. 2018]. 